\title{
Spinal Cord Compression: An Infrequent Complication of SAPHO Syndrome
}

\author{
Sonia REKIK, Maroua SLOUMA, Hela SAHLI, Elhem CHEOUR, Mohamed ELLEUCH \\ Department of Rheumatology, La Rabta Hospital, Tunis, Tunisia
}

\begin{abstract}
Synovitis, acne, pustulosis, hyperostosis, and osteitis (SAPHO) syndrome is a spectrum of inflammatory disorders including mainly rheumatologic and dermatological symptoms. In this article, we report a 50-year-old male patient of SAPHO revealed by spondylodiscitis, complicated by severe destruction, and kyphotic deformity leading to paralysis. Diagnosis was based on the association of sternoclavicular pain, palmar and plantar pustulosis, and radiological signs of inflammatory spondylodiscitis and vertebral osteitis. Computed tomography-guided discovertebral biopsy demonstrated nonspecific inflammation and culture of the specimen was negative. Nonsteroidal antiinflammatory drug treatment was initiated. One year later, the patient presented with spinal cord compression. The paralysis improved by surgery, and the patient recovered motor functions. The occurrence of spinal cord compression in SAPHO syndrome is rare. To our knowledge, less than eight cases of neurological deficit related to SAPHO syndrome have been reported in the literature. We also emphasize the effect of biological treatment in SAPHO syndrome.

Keywords: Anti-tumor necrosis factor alpha therapy; SAPHO syndrome; spinal cord compression; spondylodiscitis.
\end{abstract}

Synovitis, acne, pustulosis, hyperostosis, and osteitis (SAPHO) syndrome is a rare group of sterile, inflammatory osteoarticular disorders classically associated with skin manifestations. ${ }^{1,2}$ The etiology is unknown, probably involves genetic, infectious, and immunological factors. The characteristic feature of the disease is found in the bone lesions, which typically involve the anterior chest wall and axial skeleton. Spondylodiscitis in SAPHO syndrome is sometimes difficult to distinguish from infectious spondylodiscitis. Nonsteroidal antiinflammatory drugs are usually the efficient treatment. Cases of destructive spondylitis leading to spinal cord compression are rarely reported in the literature.

\section{CASE REPORT}

A 50-year-old male, with 10 years history of palmoplantar pustulosis, presented with a six-month history of inflammatory back pain. $\mathrm{He}$ had no significant family history. Physical examination showed restricted back movement (Schöber test was at $1.5 \mathrm{~cm}$ ) with tenderness over thoracolumbar spinal processes. His body temperature was $37.2^{\circ}$ Celsius. Dermatological examination was unremarkable.

Laboratory examination revealed a slightly elevated C-reactive protein level $(16 \mathrm{mg} / \mathrm{L})$ and erythrocyte sedimentation rate $(40 \mathrm{~mm})$. Serum levels of calcium, albumin and phosphorus were within the normal range. Blood cell counts, liver tests, and renal function were unremarkable. Blood cultures, urinanalysis, tumor markers, and serodiagnosis for brucella were negative. Tuberculosis skin test was negative. Spine magnetic resonance imaging showed low $\mathrm{T}_{1}$, high $\mathrm{T}_{2}$ signal and contrast enhancement in the $\mathrm{T}_{4} / \mathrm{T}_{5}$ and $\mathrm{L}_{3}$ vertebral body and in the $\mathrm{T}_{4} / \mathrm{T}_{5}$ disk (Figure 1). Sacroiliac joints were

Received: February 05, 2015 Accepted: March 14, 2015 Published online: May 28, 2015

Correspondence: Maroua Slouma, MD. Department of Rheumatology, La Rabta Hospital, 1007 Tunis, Tunisia.

Tel: +216551 17316 e-mail: maroua.slouma@gmail.com

○2015 Turkish League Against Rheumatism. All rights reserved. 
normal. Computed tomography-guided biopsy of the $\mathrm{T}_{4} / \mathrm{T}_{5}$ disc demonstrated nonspecific inflammation and culture of this specimen was negative. Computed tomography scan of the sternoclavicular joints revealed hyperostosis and erosions involving the sternum as well as medial end of clavicle (Figure 2). Clavicular biopsy showed irregular sclerotic trabeculae. Human leukocyte antigen B27 typing was positive.

Thus, the diagnosis of SAPHO syndrome was established. Despite the use of nonsteroidal antiinflammatory drug, the disease remained active as attested by Bath Ankylosing Spondylitis Disease Activity Index at 6.7 at three-month follow-up. Then, the patient was lost to follow-up. One year later, he presented with hypesthesia and muscle weakness of his lower limb associated with kyphotic deformity and sphincter symptoms. $\mathrm{He}$ was unable to walk. Magnetic resonance imaging showed a vertebral collapse associated with spinal cord compression at $\mathrm{T}_{5}$ (Figure 3). Surgical treatment based on decompression and reconstruction with screw fixation was performed (Figure 4). The histopathology of the specimen obtained surgically showed nonspecific osteomyelitis with an infiltration of inflammatory cells and abnormal fibrous hypertrophy among the trabecular bone. One year later, etanercept was administered at a dose of $50 \mathrm{mg}$ weekly, leading to complete resolution of articular manifestations. Clinical remission was obtained under etanercept (Bath Ankylosing Spondylitis Disease Activity Index at 2.1). After two years of follow-up, patient's paralysis improved by surgery, and he was progressively able to walk.

\section{DISCUSSION}

Synovitis, acne, pustulosis, hyperostosis, and osteitis syndrome is a rare group of sterile, inflammatory osteoarticular disorders classically associated with skin manifestations. The skin lesions are typically palmar and plantar pustulosis and acne. ${ }^{1}$ Bone and joint lesions including aseptic osteitis, hyperostosis, and synovitis may either precede, occur simultaneously or after the start of the skin lesions. In our patient, dermatological manifestations preceded the occurrence of bone and articular lesions.
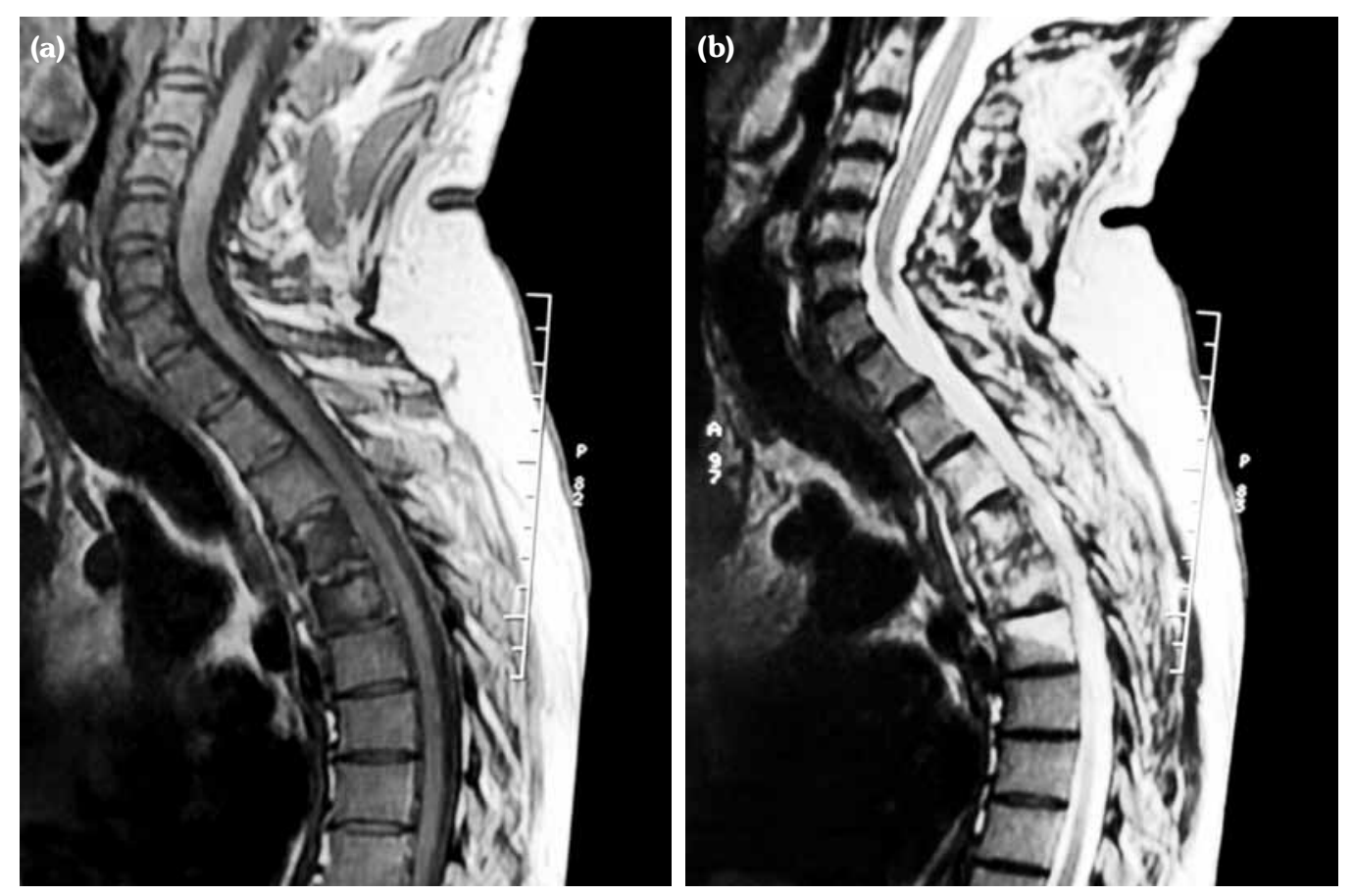

Figure 1. (a) Spine magnetic resonance imaging showing low $T_{1}$ signal in the $T_{4} / T_{5}$ vertebral body and in the $\mathrm{T}_{4} / \mathrm{T}_{5}$ disk. (b) Spine magnetic resonance imaging showing high $\mathrm{T}_{2}$ signal in the $\mathrm{T}_{4} / \mathrm{T}_{5}$ vertebral body and in the $\mathrm{T}_{4} / \mathrm{T}_{5}$ disk. 

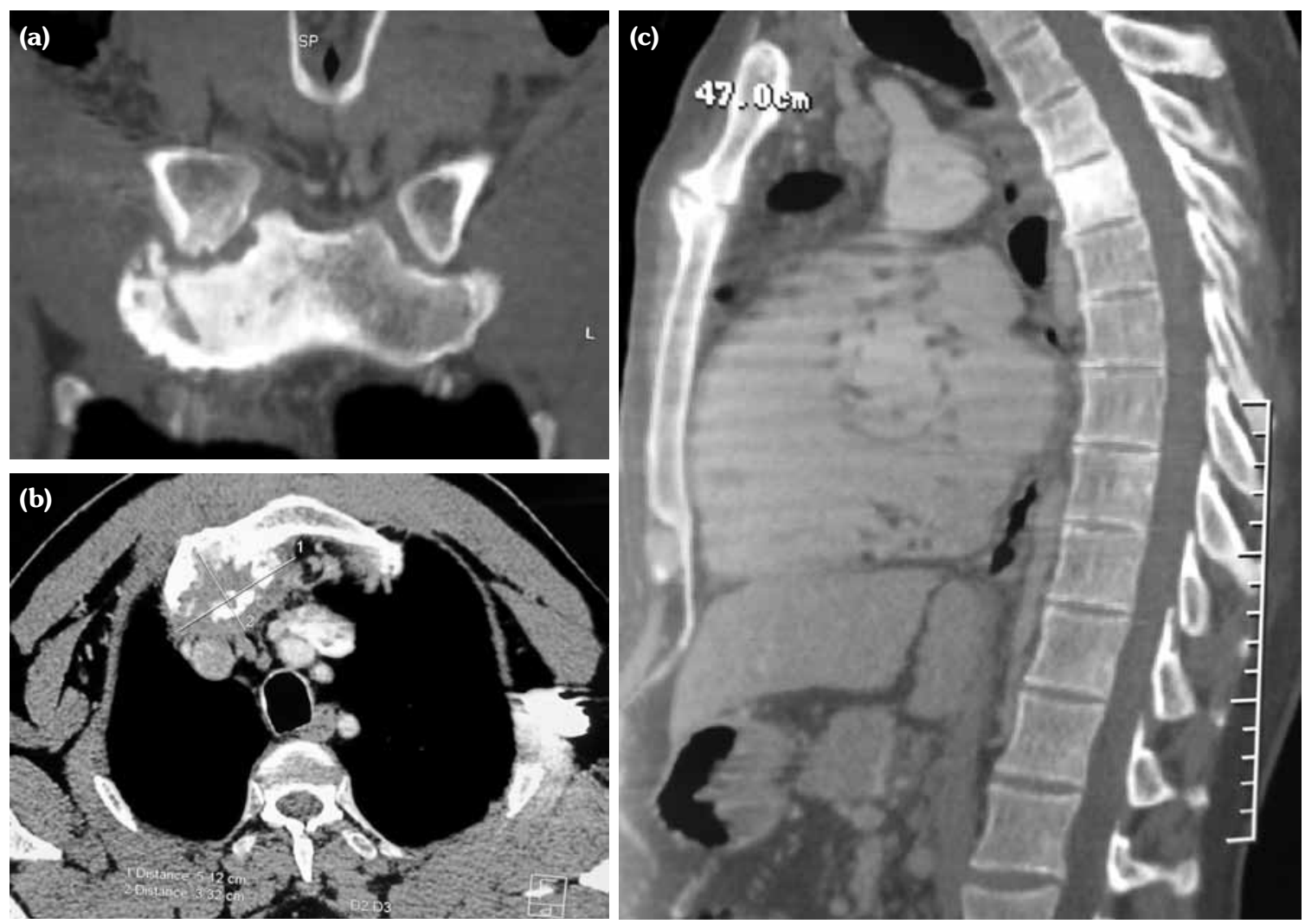

Figure 2. (a) Computed tomography scan of the sternoclavicular joints revealing hyperostosis of the medial end of the clavicles and of the manubrium sterni. (b) Computed tomography scan of the sternoclavicular joints revealing hyperostosis of the sternal region accompanied by multiple erosions of the medial end of the clavicle associated with joint destruction and beginning of ankylosis of the sternoclavicular joint. (c) Computed tomography scan of the sternoclavicular joints revealing osteosclerosis of $\mathrm{T}_{5}$ and osteitis of the manubriosternal joint.

The most common site of skeletal involvement is the anterior chest wall (70-90\%) followed by the spine, where abnormalities are found in approximately one-third of patients. ${ }^{2}$ Vertebral involvement may manifest as vertebral body osteosclerosis, hyperostosis, paravertebral ossification, lesions at the discovertebral junction, and may lead to vertebral collapse as described in our patient. ${ }^{2}$ In about $15 \%$ of cases, the enthesophytes are limited to the anterior vertebral corner. And usually, they extend to involve the adjacent vertebral endplate, the anterior vertebral cortex or the adjacent vertebral corner through the disc annulus. Involvement of at least two adjacent vertebrae is present in about $30 \%$ of cases. $^{3}$

Radiological signs of SAPHO may sometimes be difficult to differentiate from infectious spondylodiscitis and even tumors, leading to a diagnostic delay. Indeed, the intervertebral disc may be narrowed, and, in 10\% of cases, magnetic resonance imaging shows high signal intensity on $\mathrm{T}_{2}$-weighted images and gadolinium enhancement, simulating infectious spondylodiscitis. ${ }^{3-7}$

Despite the similarities of the radiological findings in inflammatory and infectious spondylodiscitis, some differences should be highlighted. As in our patient, no abscesses are observed in SAPHO syndrome. Furthermore, multiple foci of spondylodiscitis are uncommon in infection. ${ }^{5}$ Biopsy of the disk space in patients with SAPHO syndrome reveals chronic sterile nonspecific inflammation. ${ }^{6,7}$

In our patient, the diagnosis of spondylodiscitis related SAPHO syndrome was established based on the medical history of palmoplantar 


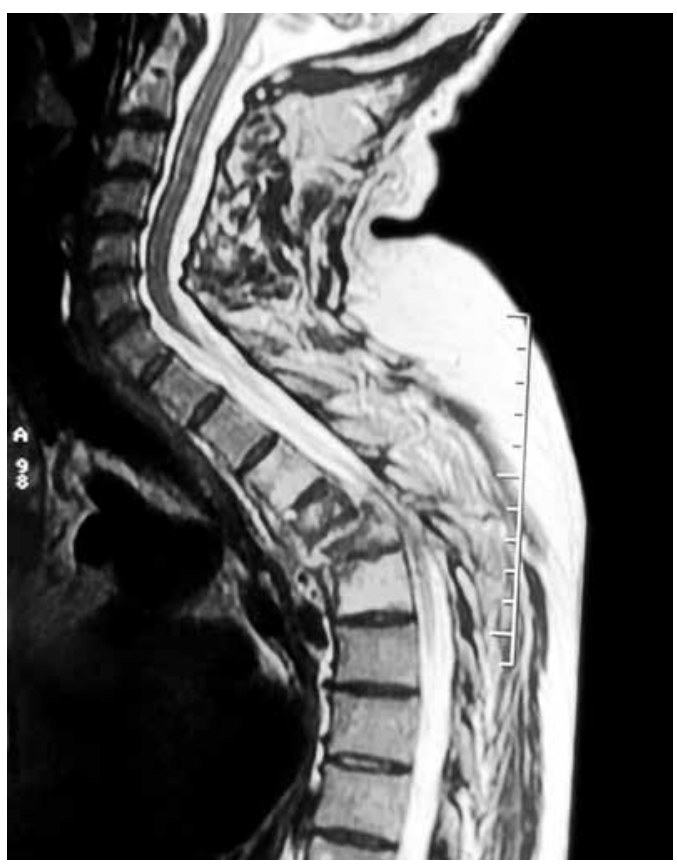

Figure 3. Lumbar magnetic resonance imaging $\mathrm{T}_{2}$-weighted sequences showing a vertebral collapse associated with spinal cord compression at $\mathrm{T}_{5}$.

pustulosis and computed tomography-guided biopsy which showed negative results for metastatic tumor or infection associated with hyperostosis, erosions involving sternum and medial end of clavicle and the presence of human leukocyte antigen B27. Indeed, in adults with SAPHO syndrome, prevalence of the human leukocyte antigen B27 is high and varies between 13 to $30 \% .^{1}$ In our patient, the main differential diagnosis was ankylosing spondylitis. However, the medical history of palmoplantar pustulosis and the presence of hyperostosis involving sternum and medial end of clavicle were against this diagnosis. The involvement of the sternoclavicular joint is uncommon, occurring in less than $4 \%$ of patients with ankylosing spondylitis. ${ }^{8}$

The spinal lesions in SAPHO syndrome usually have a good prognosis and rarely cause neurological deterioration. ${ }^{5}$ In fact, they generally have an insidious onset and repeated recurrence and remission. In SAPHO syndrome, destructive lesions progress associated with marginal sclerosis explaining why destructive spondylodiscitis progresses slowly. However, if the speed of destruction by inflammation is faster than that of sclerotic reaction, the spinal structure would break. ${ }^{8}$ We described herein a case of SAPHO syndrome complicated by severe destruction and kyphotic deformity leading to paralysis. To our
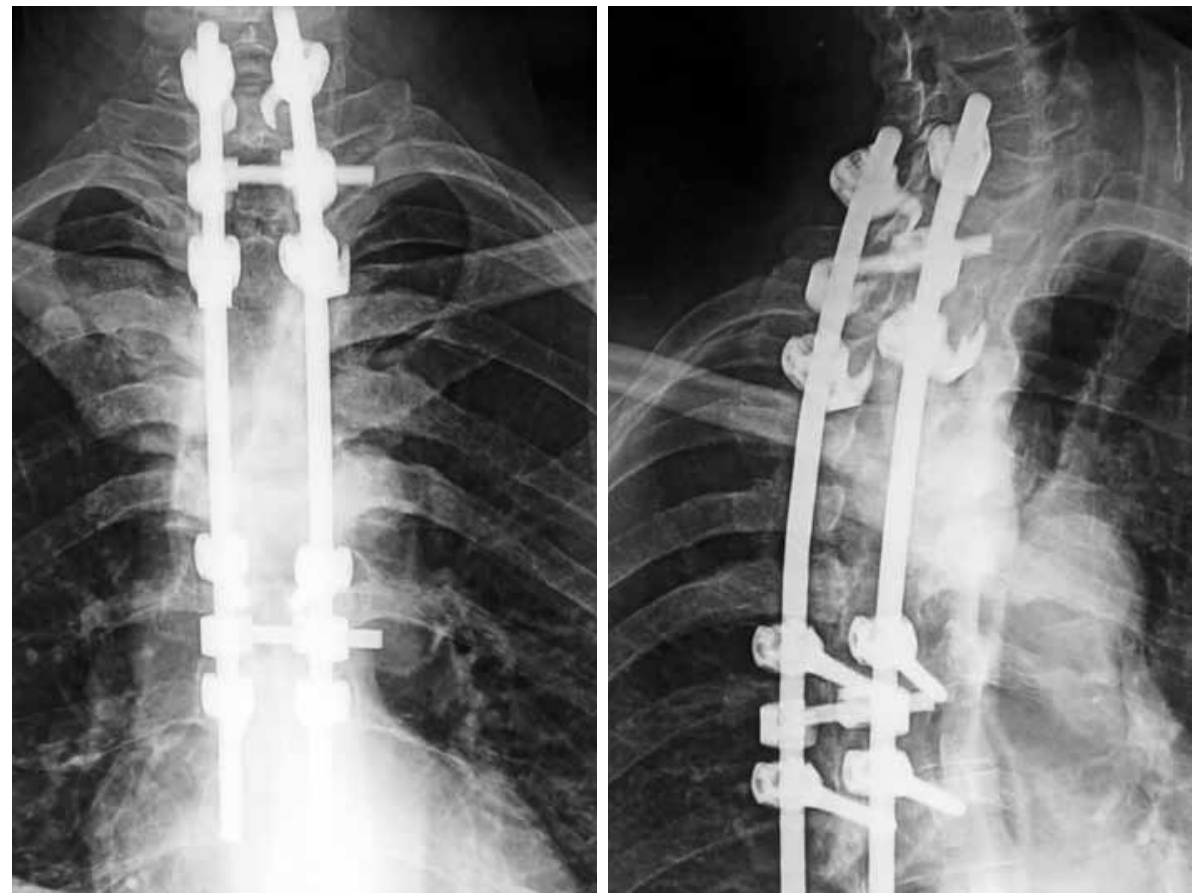

Figure 4. Postoperative spine X-ray showing posterior decompression and reconstruction. 


\begin{tabular}{|c|c|c|c|c|c|c|}
\hline Authors & Sex & Age (years) & Signs & Mechanism & Treatment & Evolution \\
\hline Deltombe et al. ${ }^{10}$ & Male & 74 & $\begin{array}{l}\text { Progressive limb } \\
\text { weakness and } \\
\text { road accident at } \\
\text { low speed }\end{array}$ & $\begin{array}{l}\text { Ankylosed spine } \\
\text { disclosed by } \\
\text { cervical spinal } \\
\text { cord } \\
\text { injury }\end{array}$ & $\begin{array}{l}\text { Conservative } \\
\text { treatment: } \\
\text { orthosis, cervical } \\
\text { immobilization and } \\
\text { rehabilitation }\end{array}$ & $\begin{array}{l}\text { Progressive clinical } \\
\text { improvement. } \\
\text { Stabilization of } \\
\text { cervical kyphosis }\end{array}$ \\
\hline Gédouin et al. ${ }^{11}$ & Female & 11 & $\begin{array}{l}\text { Progressive } \\
\text { paralysis }\end{array}$ & $\begin{array}{l}\text { Compression of } \\
\text { the cervical spinal } \\
\text { cord }\end{array}$ & & \\
\hline Fujii et al. ${ }^{12}$ & Male & 63 & $\begin{array}{l}\text { Spastic gait and } \\
\text { paraplegia }\end{array}$ & $\begin{array}{c}\text { Compression of } \\
\text { spinal cord on } \\
\mathrm{T}_{8}, \mathrm{~T}_{9} \text { level and } \\
\text { thoracic kyphosis. }\end{array}$ & $\begin{array}{l}\text { Circumferential } \\
\text { decompression } \\
\text { and fusion with } \\
\text { instrumentation. }\end{array}$ & $\begin{array}{l}\text { Improvement of } \\
\text { paraplegia }\end{array}$ \\
\hline Mulleman et al. ${ }^{13}$ & Male & 43 & $\begin{array}{l}\text { Right upper } \\
\text { limb paresis }\end{array}$ & $\begin{array}{l}\text { Ossification of } \\
\text { the posterior } \\
\text { longitudinal } \\
\text { ligament of the } \\
\text { cervical spine }\end{array}$ & & \\
\hline \multirow[t]{2}{*}{ Takigawa et al. ${ }^{8}$} & Female & 63 & $\begin{array}{c}\text { Progressive } \\
\text { quadriplegia: } \\
\text { hypesthesia and } \\
\text { muscle } \\
\text { weakness spread } \\
\text { under C5 neural } \\
\text { level. }\end{array}$ & $\begin{array}{c}\text { Severe } \\
\text { compression of the } \\
\text { spinal cord: C4-7 } \\
\text { vertebrae kyphotic } \\
\text { deformity }\end{array}$ & $\begin{array}{l}\text { Decompression } \\
\text { of spinal cord } \\
\text { using the anterior } \\
\text { approach. } \\
\text { Discectomy on } \\
\text { C3-4, C4-5, C5-6, } \\
\text { and C6-7, and } \\
\text { spondylectomy on } \\
\text { C4, C5, and C6. } \\
\text { Resection of the } \\
\text { median parts of } \\
\text { these vertebrae. }\end{array}$ & $\begin{array}{l}\text { Decrease } \\
\text { of sensory } \\
\text { disturbance }\end{array}$ \\
\hline & Female & 69 & $\begin{array}{c}\text { Persistent back } \\
\text { pain and kyphotic } \\
\text { deformity }\end{array}$ & $\begin{array}{l}\text { Compression of } \\
\text { the spinal cord: } \\
\mathrm{T}_{7}, 8 \text {, and } \mathrm{T}_{9} \text { and } \\
\text { kyphotic deformity }\end{array}$ & $\begin{array}{l}\text { Anterior approach } \\
\text { with thoracic } \\
\text { endoscope }\end{array}$ & $\begin{array}{l}\text { Absence of } \\
\text { progression } \\
\text { of kyphotic } \\
\text { deformity. } \\
\text { Improvement } \\
\text { of back pain }\end{array}$ \\
\hline Nakamura et al. ${ }^{14}$ & Female & 60 & $\begin{array}{l}\text { Persistent severe } \\
\text { low-back and } \\
\text { leg pain } \\
\text { Right-sided } \mathrm{L}_{5} \\
\text { level numbness, } \\
\text { hypoesthesia and } \\
\text { muscle } \\
\text { weakness }\end{array}$ & $\begin{array}{c}\text { Destructive } \\
\text { spondylodiscitis } \\
\text { L4}_{4}-L_{5}\end{array}$ & $\begin{array}{l}\text { Reconstructive } \\
\text { surgery of the } \\
\text { lumbar spine }\end{array}$ & $\begin{array}{c}\text { Clinical } \\
\text { improvement }\end{array}$ \\
\hline
\end{tabular}

knowledge, there are only seven cases of SAPHO syndrome with neurological deficit summarized in Table $1 .^{9-14}$ Surgery was performed leading to improved neurological signs.

Treatment of SAPHO syndrome is not yet well codified. It is often based on isolated cases and reports of small series of patients. It was demonstrated that the use of tumor necrosis factor inhibitors leads to favorable clinical outcomes in patients with SAPHO syndrome..$^{15,16}$ Similarly, clinical remission was obtained under etanercept in our patient.
The diagnosis of spondylodiscitis related to SAPHO syndrome is difficult and may be misleading. Presence of tumors and infectious spondylodiscitis should be considered in all patients. Furthermore, our case is original due to the occurrence of spinal cord compression with SAPHO syndrome. This case highlights that neurological examination is compulsory during follow-up. Proper early treatment based on tumor necrosis factor-alpha blockers may prevent further neurological damage of spondylodiscitis related to SAPHO syndrome. 


\section{Declaration of conflicting interests}

The authors declared no conflicts of interest with respect to the authorship and/or publication of this article.

\section{Funding}

The authors received no financial support for the research and/or authorship of this article.

\section{REFERENCES}

1. Hayem G, Bouchaud-Chabot A, Benali K, Roux S, Palazzo E, Silbermann-Hoffman O, et al. SAPHO syndrome: a long-term follow-up study of 120 cases. Semin Arthritis Rheum 1999;29:159-71.

2. Laredo JD, Vuillemin-Bodaghi V, Boutry $\mathrm{N}$, Cotten A, Parlier-Cuau C. SAPHO syndrome: MR appearance of vertebral involvement. Radiology 2007;242:825-31.

3. Parlier-Cuau C, Laredo J. Vertebral involvement in SAPHO syndrome. J Radiol 2010;91:1068-78.

4. Canella C, Costa F, d'Oliveira I, Albuquerque E, Marchiori E. SAPHO syndrome. Joint Bone Spine 2014;81:90.

5. Toussirot E, Dupond JL, Wendling D. Spondylodiscitis in SAPHO syndrome. A series of eight cases. Ann Rheum Dis 1997;56:52-8.

6. Perez C, Hidalgo A, Olier J, Otermin I. MR imaging of multifocal spondylodiskitis as the initial manifestations of SAPHO syndrome. AJR Am $J$ Roentgenol 1998;171:1431-2.

7. Akisue $T$, Yamamoto $T$, Marui $T$, Hitora $T$, Nagira $\mathrm{K}$, Nakatani $\mathrm{T}$, et al. Lumbar spondylodiscitis in SAPHO syndrome: multimodality imaging findings. J Rheumatol 2002;29:1100-1.
8. Robinson CM, Jenkins PJ, Markham PE, Beggs I. Disorders of the sternoclavicular joint. $\mathrm{J}$ Bone Joint Surg Br 2008;90:685-96.

9. Takigawa T, Tanaka M, Nakahara S, Sugimoto Y, Ozaki T. SAPHO syndrome with rapidly progressing destructive spondylitis: two cases treated surgically. Eur Spine J 2008;17:331-7.

10. Deltombe T, Nisolle JF, Boutsen Y, Gustin T, Gilliard C, Hanson P. Cervical spinal cord injury in sapho syndrome. Spinal Cord 1999;37:301-4.

11. Gédouin JE, Violas P, Chapuis M, Bracq H. Stiff painful spine in an 11-year-old girl with SAPHO syndrome. Rev Chir Orthop Reparatrice Appar Mot 2001;87:830-4.

12. Fujii T, Matsudaira K, Oda $H$, Seichi A, Nakamura $\mathrm{K}$. A case of SAPHO syndrome with paraplegia due to a thoracic kyphosis. Ryumachi 2002;42:687-93. [Abstract]

13. Mulleman D, Mammou S, Griffoul I, Goupille P, Valat JP. Ossification of the posterior longitudinal ligament of the cervical spine and SAPHO syndrome. J Rheumatol 2005;32:1361-4.

14. Nakamura J, Yamada K, Mitsugi N, Saito T. A case of SAPHO syndrome with destructive spondylodiscitis suspicious of tuberculous spondylitis. Mod Rheumatol 2010;20:93-7.

15. Massara A, Cavazzini PL, Trotta F. In SAPHO syndrome anti-TNF-alpha therapy may induce persistent amelioration of osteoarticular complaints, but may exacerbate cutaneous manifestations. Rheumatology (Oxford) 2006;45:730-3.

16. Vilar-Alejo J, Dehesa L, de la Rosa-del Rey P, NovoaMedina J, Valerón Almazán P, Santana Medina N, et al. SAPHO syndrome with unusual cutaneous manifestations treated successfully with etanercept. Acta Derm Venereol 2010;90:531-2. 